Tibuana

Journal of applied Industrial Engineering-University of PGRI Adi Buana

$p$-ISSN 2622-2027

DOI : https://doi.org/10.36456/tibuana.4.02.3770.69-82

$e$-ISSN 2622-2035

\title{
Crashing Project Evaluation by Managing Allocation Resource and Cost using CPM-PERT and MS,Project in Nurul Hayat Mosque's Renovation
}

\author{
Nur Rizka Athira ${ }^{1}$, Dea Ayu Maharani Andris ${ }^{2}$, Siti Muhimatul Khoiroh ${ }^{3}$ \\ 1,2,3 Industrial Engineering Department, Engineering Department - Universitas 17 Agustus 1945 Surabaya \\ Email : siti_muhimatul@untag-sby.ac.id
}

\begin{abstract}
The implementation of project management must be calculated based on time and cost estimation. One of the efficiency measures that can take is to accelerate. Time, cost, and quality are factors that must consider while making project acceleration. Project renovation in Nurul Hayat's room was chosen in this research because this project experienced delays in implementation. Delays occur due to a lack of available manpower. This delay will certainly have an impact on costs. The purpose of this research is to speed up time and get optimum costs while still paying attention to quality standards. By CPM-PERT approach, and the evaluation of project acceleration with Ms. Project, the results obtained are scheduling the initial completion of the mosque renovation which initially has an estimated 42 days with a normal total cost of $17,227,500$, can be accelerated for 36 working days with additional processing costs of Rp. 70,000 and overtime costs of Rp. 1,635,000. The total cost is $\mathrm{Rp}$ $18,932,500$.
\end{abstract}

Keyword : Crashing Project, CPM-PERT, Ms. Project

\section{INTRODUCTION}

Project management is the process of planning, organizing, leading, and controlling the activities of organizational members and other resources so that they can achieve predetermined organizational goals (Dimyati \& Nurjaman, 2014).

In the implementation process, the project management process will be faced with several constraints that are commonly faced, including time constraints, limited costs, and limited human resources. One project that has a small scope in the Surabaya area, precisely on Jalan Simorejo Sari Gang B No.17 is the renovation project for the Nurul Himah prayer room. This mosque has the size of the room to be renovated of $15 \times 10 \mathrm{~m}^{2}$.

Based on the observation, the sketch of renovation building are :

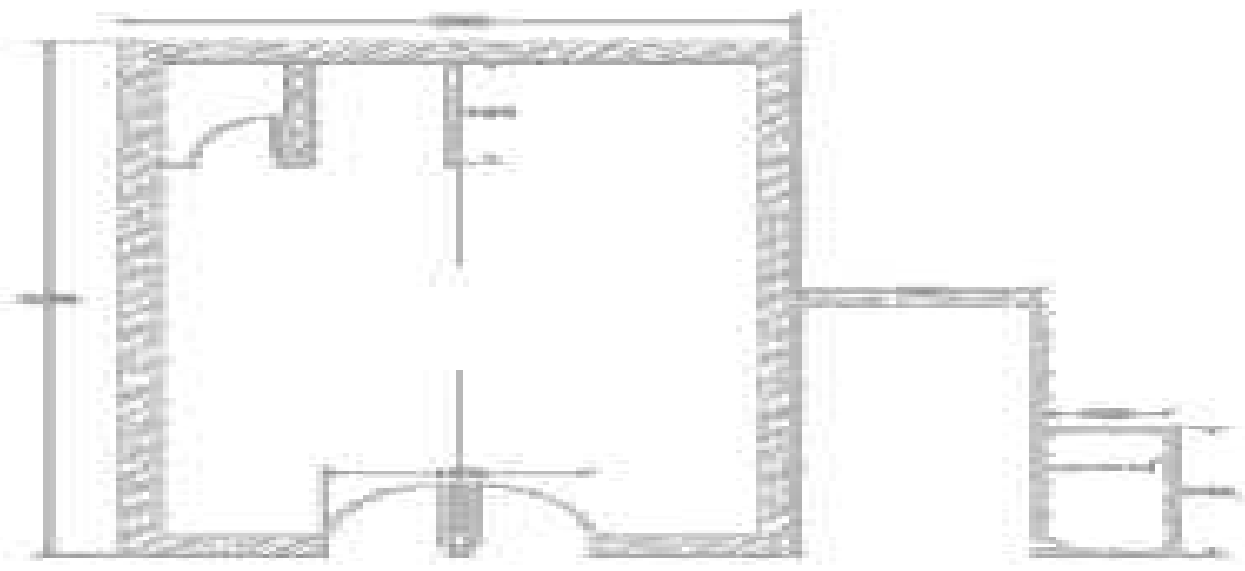

Figure 1. Skecth of mosque's renovation

From the results of observations, it is known that the renovation of the mosque is planned to be completed in 42 working days with a budget of Rp. 17,292,500, with a total of 5 workers. However, due to the pandemic, various forms of material needs have increased and the situation in the implementation of the Covid-19 prevention has made the activity implementers hope that the project for completing the renovation of the room at the prayer room can 


\section{Tibuana}

Journal of applied Industrial Engineering-University of PGRI Adi Buana

DOI : https://doi.org/10.36456/tibuana.4.02.3770.69-82

be completed in a faster time but by still paying attention to the addition of minimal costs.

The purpose of this study is to help evaluate the possibility of accelerating the Nurul Hikmah prayer room renovation project with various possibilities including the possibility of increasing labor overtime or increasing the number of workers by considering the cost of using the CPM-PERT approach and Crashing project with evaluation of resource scheduling on the network. project with Ms. Projects.

\section{RESEACH METHOD}

\section{A. Project Management}

A project consists of a series of sequences long activity and started since put ideas, planned, then implemented, until it actually gives results according to plan.So the project is a process of combining a series of temporary activities that contains a starting point and an end point, which involves a variety of resources that are limited or certain to achieve the target and goals that have been set ( (Wohon, Mandagi, \& Pratasis, 2015).

Project management is the application of science knowledge, expertise, and skills, technical methods the best with limited resources, to achieve the goals and objectives that have been determined to get optimal results in terms of cost, quality and time performance, as well as work safety (Abror, 2008).

\section{B. CPM-PERT}

Working on a project with the CPM method exposes dependency logic. The dependency logic is then made a network or network planning. Making this network is intended to determine the critical path (Gunasti, Rofiqi , \& Priyono, 2019).

The benefits of critical trajectory information on projects are (Dannyanti, 2011) :

a. Delayed work on the critical path will result in delays in the completion of the entire project.

b. Acceleration of work can be done if the activity on the critical path is accelerated.

c. Project control through the critical path can be done by controlling the existing trade offs (the most likely/efficient exchange of time and cost) with crashing the project.

d. For activities that are not included in the critical path, it is possible to transfer labor, tools and costs to complete work on the critical path.

Meanwhile, in project scheduling using the PERT method, it starts by estimating the completion time of each project activity item into 3 types of time estimates, namely optimistic time (a), most likely time (m), and pessimistic time (b) (Abdurrasyid, Luqman, Haris, \& Indrianto, 2019).

In the process of identifying the critical path, the first thing carried out is a backward pass and calculate forward pass. Calculation forward pass in PERT and CPM method is performed to be able to calculate the earliest finish time of a job (EF), the fastest start time for a job to occur

job (ES) and the earliest start of a job (E), starting from Start (initial event) to Finish (terminal events). While the backward calculation pass) is done to get the time calculation the latest completion of a job (LF), time no later than the occurrence of a job (LS) and when no later than the start of a job (L), starting from Finish to Start. After completing the calculations forward and countdown, the next to be carried out is the calculation of the time allowance (float/ slack) of activities consisting of total float and free float. If an activity does not have leeway or in other words $\mathrm{S}=\mathrm{SF}=0$ then the activity are called critical activities. These critical activities will form a critical path which usually starts from the start (initial event) to finish (terminal event) (Herjanto, 2008). The steps in making PERT are:

1. Identify activities and events

2. Determine the sequence of activities

3. Create network diagrams

4. Estimated time for each activity

5. Specify the critical path

6. Update the diagram according to the progress of the project

The network planning step using the PERT approach is intended to find out what the probability value of project activities is, especially on the critical path, is completed on time according to the expected schedule (Utomo, Hendriyani, \& Aida, 2020).

1. Determine the variety of activities from project activities :

$\mathrm{Te}=(\mathrm{a}+4 \mathrm{~m}+\mathrm{b}) / 6$ 
Tibuana

Journal of applied Industrial Engineering-University of PGRI Adi Buana

DOI : https://doi.org/10.36456/tibuana.4.02.3770.69-82

Information:

$\mathrm{Te}=$ estimated activity time

$\mathrm{a}=$ most optimistic time

$\mathrm{m}=$ normal time

$\mathrm{b}=$ most pessimistic time

2. Determine the standard deviation of project activities :

$S=(1 / 6) \times(b-a)$

Information:

$\mathrm{S}=$ activity standard deviation

$\mathrm{a}=$ most optimistic time

$\mathrm{b}=$ most pessimistic time

3. Determine the variety of activities from project activities :

$\mathrm{V}(\mathrm{te})=\mathrm{S}^{2}$.

Information:

$\mathrm{V}(\mathrm{te})=$ activity variance

$\mathrm{S}=$ activity standard deviation

$\mathrm{a}=$ optimistic time

$\mathrm{b}=$ pessimistic time

4. Knowing the Probability of achieving the target schedule :

$\mathrm{Z}=(\mathrm{Td}-\mathrm{Te}) / \mathrm{S}$

Information:

$\mathrm{Z}=$ activity variance

$\mathrm{T}(\mathrm{d})=$ activity standard deviation

$\mathrm{Te}=$ optimistic time

$\mathrm{S}=$ pessimistic time

The number $\mathrm{z}$ is a probability number whose percentage can be found using the cumulative normal distribution table $\mathrm{z}$.

\section{DIFFERENCE BETWEEN CPM AND PERT}

PERT and CPM methods have the following differences (Herjanto, 2008):

1. The application of the method, the PERT method is used in project planning and control that has never been done before, while the CPM method is used to schedule and control activities that have been done before so that the time, data, and costs of each activity element are known in advance by the evaluator .

2. Processing time, the PERT method uses three types of processing time, namely the fastest, the longest and the most feasible, while the CPM method only consists of one type of processing time information, namely the most appropriate and appropriate time to complete a project.

3. The focus of the method, in the PERT method, the focus is on the timeliness factor, because according to this method, by cutting time, it has an impact on decreasing project costs, while in the CPM method the focus is on the accuracy of the project cost plan with the realization.

4. In the PERT method the arrows indicate the order (presidential relationship) while in the CPM the arrows are activities.

\section{CRASHING PROJECT}

The crashing process is a process of reducing or reducing the duration of a job that will affect the project completion time. Crashing is a deliberate, systematic and analytic process by testing all activities in a project centered on activities that are on the critical path ( Simatupang, Dundu, \& Sibi, 2015).

Crashing process is a way to estimate variable costs in determining the most optimal and economical reduction in the duration of a project activity that is still possible to be reduced. Crashing can lead to a trade off between cost and time (Arianie \& Puspitasari, 2017).

Accelerating the duration of an activity will increase costs, but will not necessarily shorten the overall project time.

Unless the activity is a critical activity. That is why we need the best combination of activities that accelerate the duration of their implementation in producing the most economical project time, where our goal is to complete a technical and economical project requires a careful calculation to where we can shorten the time by adding the smallest possible cost. . Activities in a project can be accelerated in various ways, namely:

a. By holding work shifts, it means additional costs in the form of costs for lighting, meals and so on. 


\section{Tibuana}

Journal of applied Industrial Engineering-University of PGRI Adi Buana

DOI : https://doi.org/10.36456/tibuana.4.02.3770.69-82

b. By extending working time (overtime).

c. By using more productive tools.

d. Increase the number of workers

e. By using materials that can be faster installation.

f. Using another construction method which is faster.

\section{E. RESEARCH METHODOLOGY}

Based on the observation and knowing the concept of project management and some technique to calculate and evaluate the scheduling project and how to make a crashing project scheduling, in this research the sequences of methodology figure below:

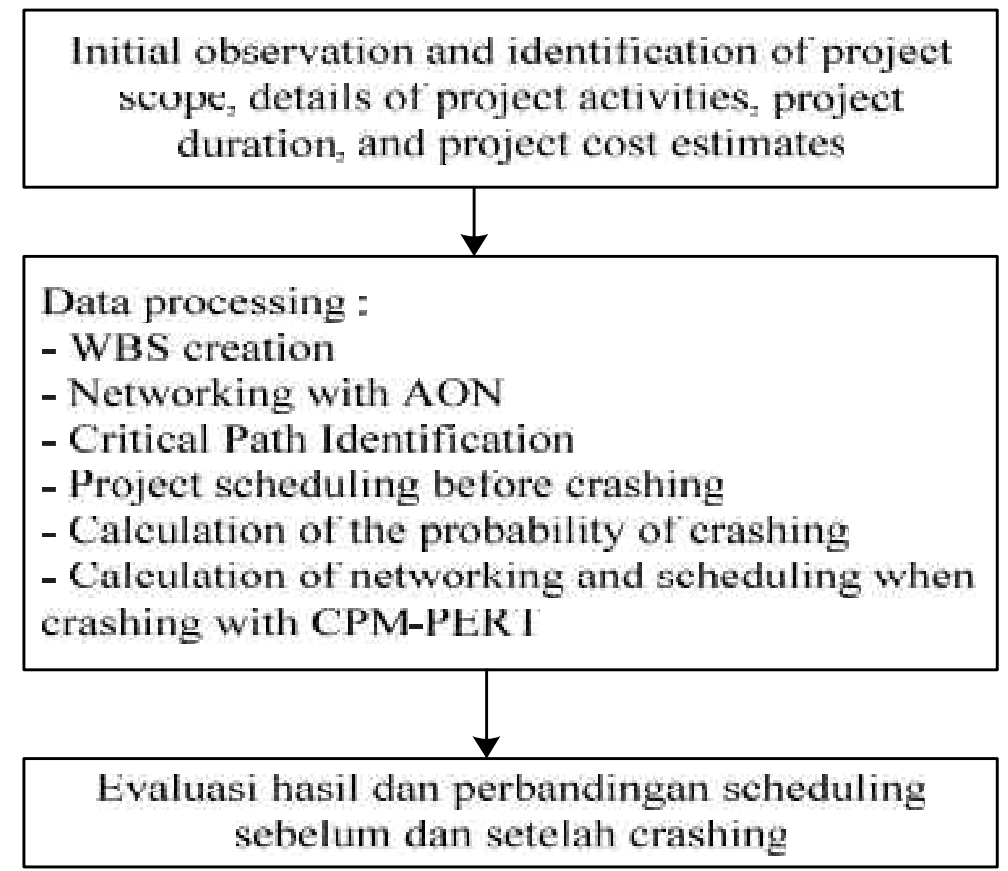

Figure 2. Flowchart

\section{RESULTS AND DISCUSSION}

The research we did was started with observation to get the project data "Renovation of Musholla Nurul Hikmah" which is located at Jalan Simorejo Sari B Gang 17, No. 17 Surabaya. Then we process the data as "Project Planning and Control" by including problems that we will solve manually and automatically in the MS Project Application to find out the differences between the 2 methods.
This project is a mosque renovation project which has a land area of $15 \times 10 \mathrm{~m}^{\wedge} 2$. What will be carried out in this renovation project are Roof Renovation, Wall Renovation, Floor Renovation, Fence Renovation, and Renovation of Electrical Installations.

Here are the data we got:
A. Work Breakdown Structure (WBS) 


\section{Tibuana}

Journal of applied Industrial Engineering-University of PGRI Adi Buana

DOI : https://doi.org/10.36456/tibuana.4.02.3770.69-82

Table 1. WBS

\begin{tabular}{|l|l|l|}
\hline I. & \multicolumn{2}{|l|}{ Planing } \\
\hline & 1.1 & Observation of Renovation Sites \\
\hline & 1.2 & Determination of Work Activities \\
\hline & 1.3 & $\begin{array}{l}\text { Determination of Renovation \& Establishment of } \\
\text { Working Group }\end{array}$ \\
\hline & 1.4 & Material Preparation \\
\hline II. & Roof Repair \& Roof Renovation \\
\hline & 2.1 & Ceiling Removal \\
\hline & 2.2 & Roof Support Wood Renovation \\
\hline & 2.3 & Ceiling Installation \\
\hline & 2.4 & Cement plaster on ceiling joints sambungan \\
\hline & 2.5 & Plamir ceiling \\
\hline III. & Wall & Renovation \\
\hline & 3.1 & Peeling old paint \\
\hline & 3.2 & Front pole reinforcement \\
\hline & 3.3 & Front pillar plaster \\
\hline & 3.4 & Plamir Wall \\
\hline & 3.5 & Repaint \\
\hline IV. & Floor Renovation \\
\hline & 4.1 & Previous plaster floor fix \\
\hline & 4.2 & Installation of the rope barrier \\
\hline & 4.3 & Tackle installation \\
\hline & 4.4 & Charging between tackles \\
\hline & 4.5 & Tackle Cleaning \\
\hline V. & Fence Renovation \\
\hline & 5.1 & Fence Removal \\
\hline & 5.2 & Sandpaper fence paint \\
\hline & 5.3 & Repainting the fence \\
\hline & 5.4 & Installation of fences \\
\hline VI. & Finishing \\
\hline & 6.1 & Electrical \& Water installations \\
\hline & 6.2 & Installation of the contents of the mosque \\
\hline & \multicolumn{2}{|c|}{} \\
\hline
\end{tabular}

Table 1. are the details of the activities that occurred in the mosque renovation project which began with planning activities and ended with finishing activities.

\section{B. OBS}

Table 2. OBS

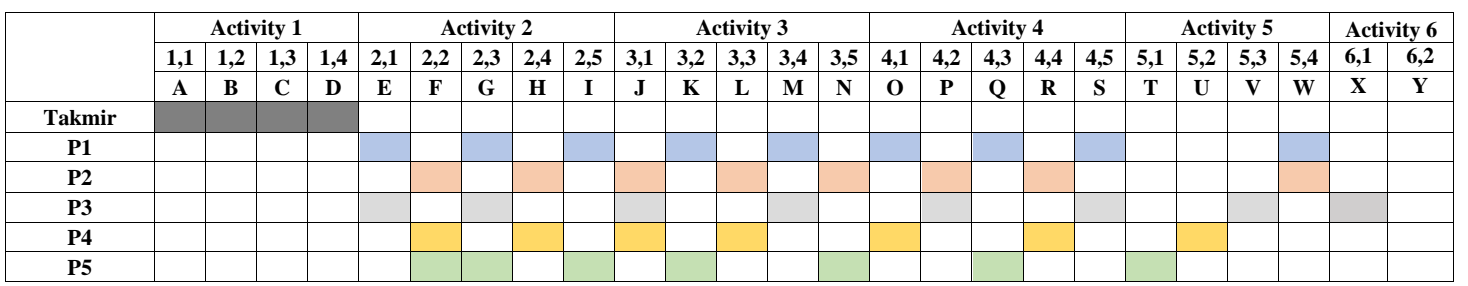

P1 - P2 : Professional Builder

P3 - P5 : Handyman / Coolie

The following is a breakdown of the number of worker activities that occur in each activity.

C. Costs Activities

Table 3. Costs Project Activities

\begin{tabular}{|c|c|c|c|c|}
\hline Activity & Cost & Activity & & Cost \\
\hline 1.1 & & 3.5 & $\mathbf{R p}$ & 1.960 .000 \\
\hline 1.2 & & 4.1 & $\mathbf{R p}_{\mathbf{p}}$ & 480.000 \\
\hline 1.3 & & 4.2 & $\mathbf{R p}$ & 165.000 \\
\hline 1.4 & & 4.3 & $\mathbf{R p}$ & 1.980 .000 \\
\hline 2.1 & 320.000 & 4.4 & $\mathbf{R p}$ & 510.000 \\
\hline 2.2 & $\mathrm{Rp}_{\mathrm{p}} 2.713 .000$ & 4.5 & $\mathbf{R p}$ & 160.000 \\
\hline 2.3 & $\mathrm{RP}_{\mathrm{P}} 2.828 .000$ & 5.1 & $\mathbf{R p}$ & 70.000 \\
\hline 2.4 & $\mathrm{RP}_{\mathrm{p}} 1.360 .000$ & 5.2 & $\mathbf{R p}$ & 82.000 \\
\hline 2.5 & $\mathrm{RP}_{\mathrm{p}} 1.220 .000$ & 5.3 & $\mathbf{R p}$ & 197.000 \\
\hline 3.1 & $\mathrm{RP}_{\mathrm{P}} \mathbf{7 2 0 . 0 0 0}$ & 5.4 & $\mathbf{R p}$ & 170.000 \\
\hline 3.2 & 560.000 & 6.1 & $\mathbf{R}_{\mathbf{p}}$ & 490.000 \\
\hline 3.3 & 405.000 & 6.2 & $\mathbf{R p}_{\mathbf{p}}$ & 25.000 \\
\hline 3.4 & 812.500 & Total & Rp & 17.227 .500 \\
\hline
\end{tabular}

So, the total cost of raw materials and labor costs is IDR $17,227,500$. 


\section{Tibuana}

Journal of applied Industrial Engineering-University of PGRI Adi Buana

DOI : https://doi.org/10.36456/tibuana.4.02.3770.69-82

D. Gantt Chart

Table 4. Gantt Chart

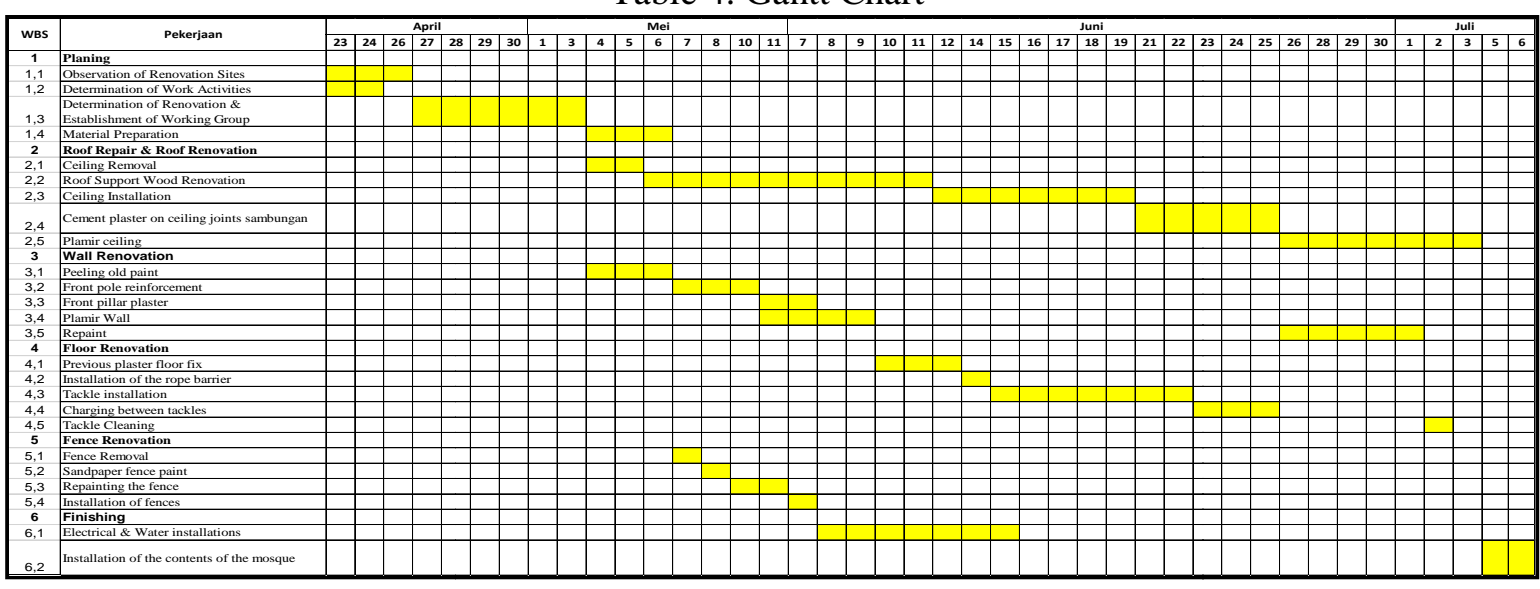

Table 4. is a detailed project date of each activity and this project will start from 23 April 2021 and end on 6 July 2021.

E. Job Details

Table 5. Job Detail

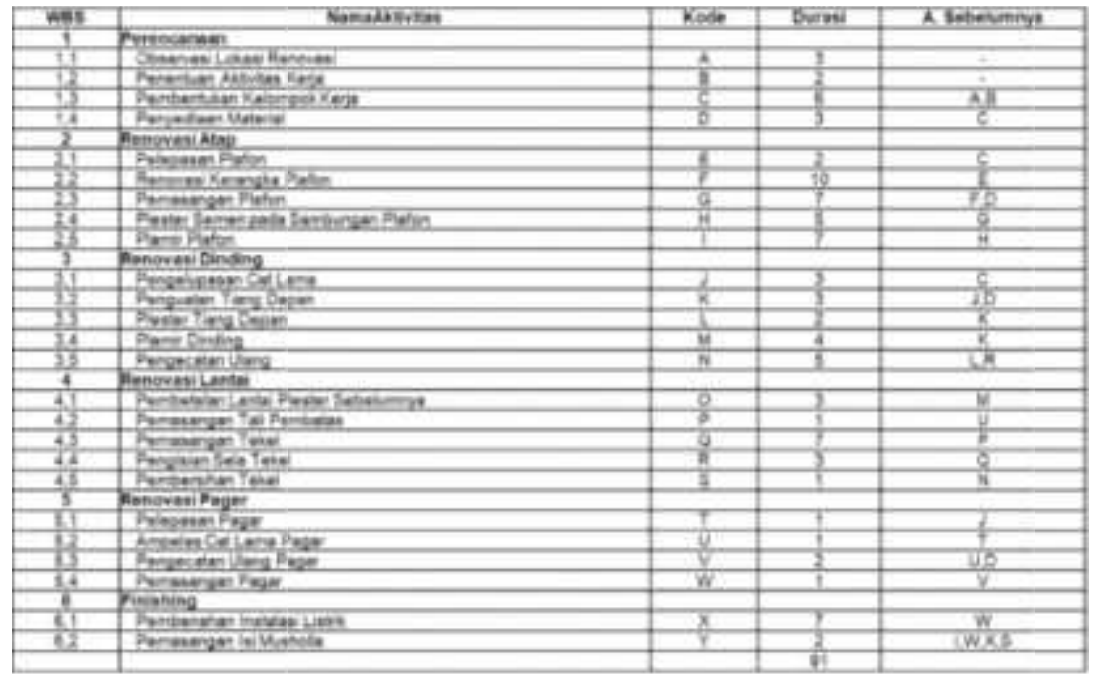

From the data in Table 5. we

get, we will process it as "Project Planning and Control". 
Tibuana

Journal of applied Industrial Engineering-University of PGRI Adi Buana

$p$-ISSN 2622-2027

DOI : https://doi.org/10.36456/tibuana.4.02.3770.69-82

$e$-ISSN 2622-2035

\section{F. Network AON}

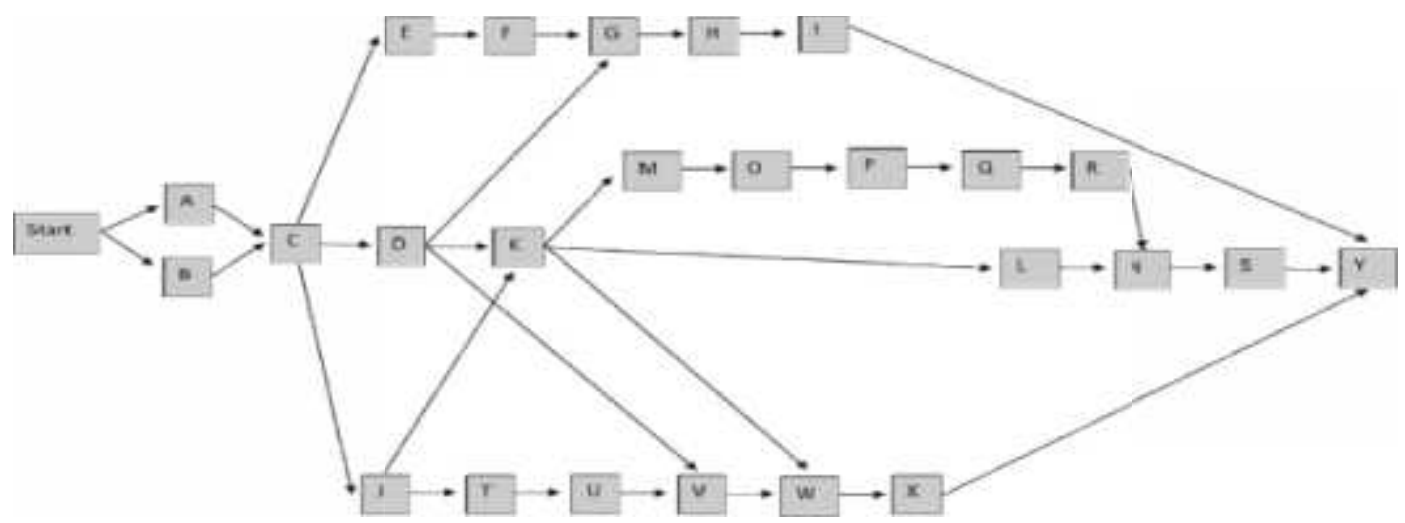

Figure 3. AON Network

Once we get the detailed sequence of activities as well as the activities that preceded it, we can create an $\mathrm{AON}$ path with the existing data.

G. AON Calculation

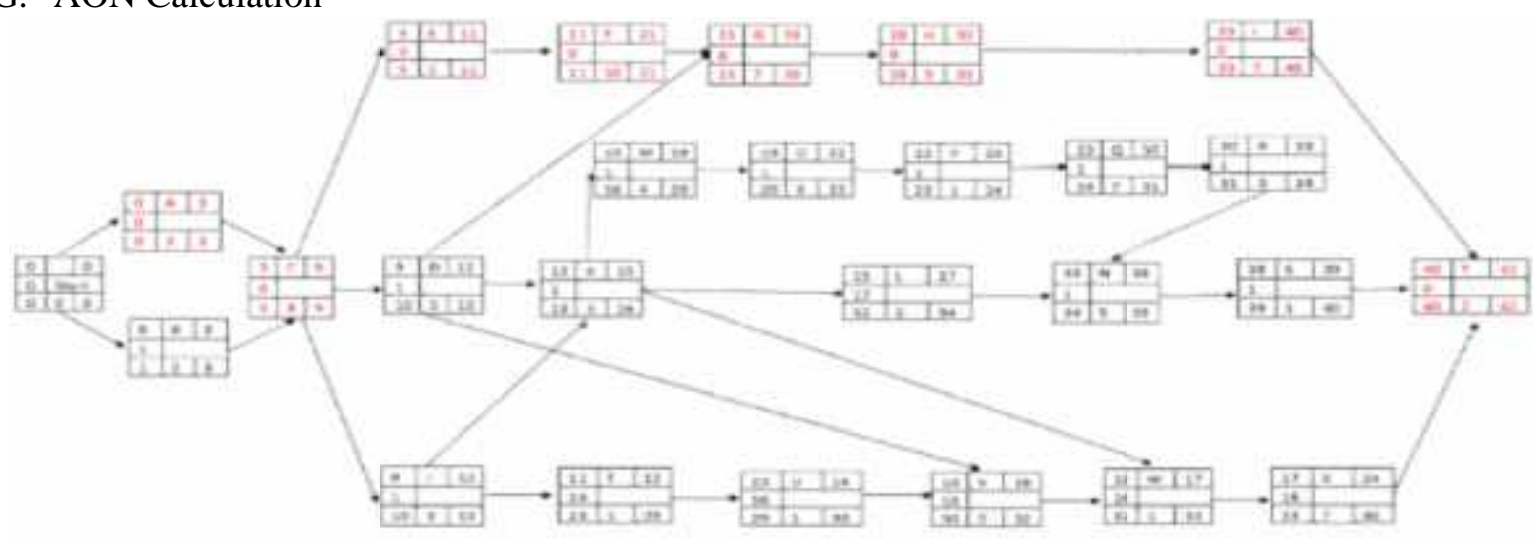

Figure 4. Total Duration

After we know the Network, we can calculate the forward and backward calculation with a predetermined duration. So, we get the length of time for the project for 42 days and the critical path of the project is $\mathrm{A}-$ $\mathrm{C}-\mathrm{E}-\mathrm{F}-\mathrm{G}-\mathrm{H}-\mathrm{I}-\mathrm{Y}$.
H. CPM-PERT

After that, we look for the optimistic time is the fastest completion time, the most likely time is the duration time, while the pessimistic time is the maximum time needed for the project. After that calculate te and variance. 
Tibuana

Journal of applied Industrial Engineering-University of PGRI Adi Buana

DOI : https://doi.org/10.36456/tibuana.4.02.3770.69-82

Table 6. Data Calculation for Knowing value of probalitity crashing

\begin{tabular}{|c|c|c|c|c|c|c|}
\hline \multirow[b]{2}{*}{ Activities } & \multicolumn{5}{|c|}{ Time (Day) } & \multirow[b]{2}{*}{ |eliminary Activiti } \\
\hline & Optimistic (a) & Most Likely (m) & pessimist (b) & Te & Varians & \\
\hline $\mathbf{A}$ & 3 & 3 & 3 & 3.0 & 0,00 & \\
\hline $\mathbf{B}$ & 2 & 2 & 2 & 2.0 & 0,00 & \\
\hline C & 2 & 6 & 6 & 5.3 & 0,44 & $A, B$ \\
\hline $\mathbf{D}$ & 2 & 3 & 8 & 3.7 & 1,00 & $C$ \\
\hline$E$ & 1 & 2 & 3 & 2.0 & 0,11 & C \\
\hline $\mathbf{F}$ & 8 & 10 & 14 & 10.3 & 1,00 & E \\
\hline $\mathbf{G}$ & 6 & 7 & 12 & 7.7 & 1,00 & F,D \\
\hline $\mathbf{H}$ & 3 & 5 & 7 & 5.0 & 0,44 & $G$ \\
\hline 1 & 6 & 7 & 12 & 7.7 & 1,00 & $\mathbf{H}$ \\
\hline$J$ & 2 & 3 & 4 & 3.0 & 0,11 & C \\
\hline K & 4 & 3 & 6 & 3.7 & 0,11 & $J, D$ \\
\hline $\mathbf{L}$ & 1 & 2 & 3 & 2.0 & 0,11 & $K$ \\
\hline$M$ & 3 & 4 & 5 & 4.0 & 0,11 & K \\
\hline $\mathbf{N}$ & 3 & 5 & 7 & 5.0 & 0,44 & $L, R$ \\
\hline $\mathrm{O}$ & 2 & 3 & 4 & 3.0 & 0,11 & $M$ \\
\hline $\mathbf{P}$ & 1 & 1 & 1 & 1.0 & 0,00 & $U$ \\
\hline$a$ & 6 & 7 & 12 & 7.7 & 1,00 & $P$ \\
\hline $\mathrm{R}$ & 1 & 3 & 5 & 3.0 & 0,44 & $a$ \\
\hline$s$ & 1 & 1 & 1 & 1.0 & 0,00 & $\mathbf{N}$ \\
\hline$T$ & 1 & 1 & 1 & 1.0 & 0,00 & $J, D$ \\
\hline$U$ & 1 & 1 & 1 & 1.0 & 0,00 & $T$ \\
\hline $\mathrm{V}$ & 2 & 2 & 2 & 2.0 & 0,00 & $U, D$ \\
\hline$w$ & 1 & 1 & 1 & 1.0 & 0,00 & V \\
\hline$x$ & 6 & 7 & 12 & 7.7 & 1,00 & $w$ \\
\hline $\mathrm{Y}$ & 1 & 2 & 3 & 2.0 & 0,11 & $W, x, s$ \\
\hline
\end{tabular}

I. Probability of Crashing

Project Duration Acceleration

Opportunity

Project variance

$=($ variance of activities on the critical path)

$=$ variance $\mathrm{A}+$ variance $\mathrm{C}+$ variance $\mathrm{E}+$ variance $\mathrm{F}+$ variance $\mathrm{G}+$ variance $\mathrm{H}+$ variance $\mathrm{I}+$ variance $\mathrm{Y}$

$=0+0.44+0.11+1+1+0.44$

$+1+0.11$

$=4.1$

Project standard deviation(s)

$=$ Project Variance $=4,1$
$=2.02$

If you want to speed up the project time to 36 days, then the opportunities are as follows:

$$
\begin{aligned}
& \mathbf{z}=\left(T_{-} \mathbf{s}-T_{-} \boldsymbol{e}\right) / \sqrt{ }\left(V_{-} \boldsymbol{p}\right) \\
& \mathbf{z}=(\mathbf{3 6}-\mathbf{4 2}) /(\mathbf{2}, 02) \\
& \mathbf{z}=-\mathbf{2}, 97
\end{aligned}
$$

Based on the Standard Deviation, if the project is accelerated by 36 days, then the probability is 0.0015 or $0.15 \%$

J. Effect of Limited Human Resources on Project Duration (Resource Scheduling)

Table 7. Resource Scheduling

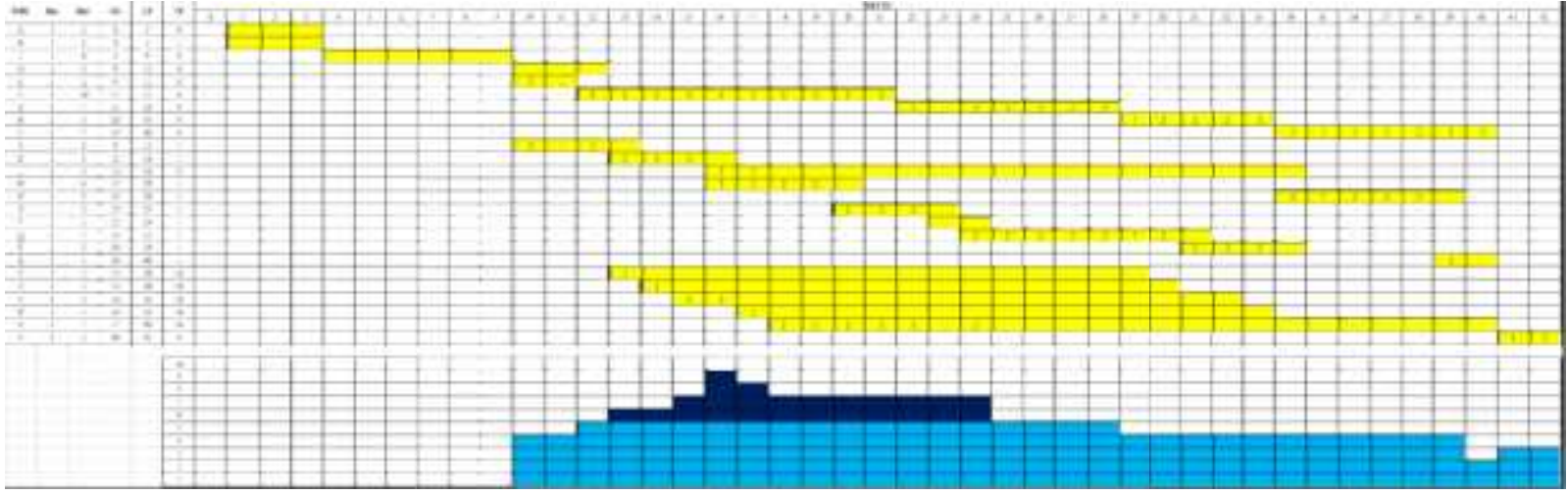




\section{Tibuana}

Journal of applied Industrial Engineering-University of PGRI Adi Buana

DOI : https://doi.org/10.36456/tibuana.4.02.3770.69-82

Table 8. Aloocation of Resource Scheduling

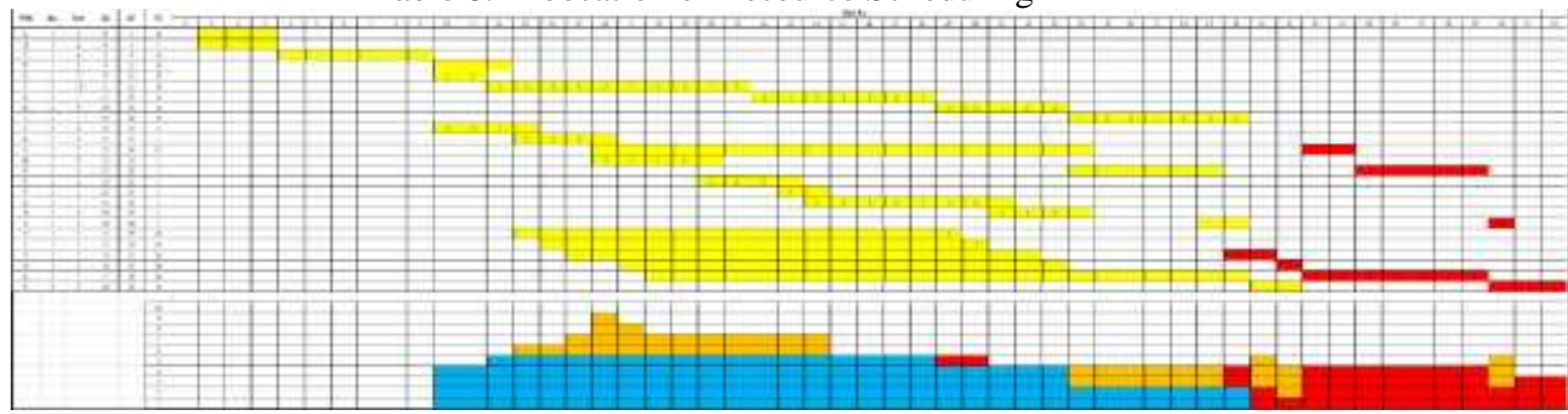

From the Resource Scheduling for the allocation of HR, we get a setback for 10 days.

K. Effect of Duration Limitation on Cost Addition (Crashing)

Table 9. Costs of Crashing Project Estimation

\begin{tabular}{|c|c|c|c|c|c|c|}
\hline Activity & \multirow{2}{*}{$\frac{\text { Normal Time }}{3}$} & \multicolumn{2}{|c|}{ Acceleration Time } & \multicolumn{2}{|c|}{ Normal Cost } & Acceleration Fee \\
\hline A & & & 3 & $\mathbf{R p}_{\mathbf{p}}$ & - & $\mathrm{Rp}_{\mathrm{p}}$ \\
\hline $\mathbf{B}$ & 2 & & 2 & $\mathbf{R p}_{\mathbf{p}}$ & - & $\mathbf{R p}_{\mathbf{p}}$ \\
\hline C & 6 & & 2 & $\mathbf{R}_{\mathbf{p}}$ & - & $\mathbf{R p}_{\mathbf{p}}$ \\
\hline $\mathbf{D}$ & 3 & & 2 & $\mathbf{R}_{\mathbf{p}}$ & - & $\mathbf{R}_{\mathbf{p}}$ \\
\hline $\mathbf{E}$ & 2 & & 1 & $\mathbf{R p}_{\mathbf{p}}$ & 320.000 & 550.000 \\
\hline $\mathbf{F}$ & 10 & & 8 & $\mathbf{R}_{\mathbf{p}}$ & 2.713 .000 & 3.073 .000 \\
\hline G & 7 & & 6 & $\mathbf{R p}_{\mathbf{p}}$ & 2.828 .000 & 3.248 .000 \\
\hline $\mathbf{H}$ & 5 & & 3 & $\mathbf{R p}_{\mathbf{p}}$ & 1.360 .000 & 1.570 .000 \\
\hline $\mathbf{I}$ & 7 & & 6 & $\mathbf{R p}_{\mathbf{p}}$ & 1.220 .000 & 1.290 .000 \\
\hline $\mathbf{J}$ & 3 & & 2 & $\mathbf{R p}_{\mathbf{p}}$ & 720.000 & 580.000 \\
\hline $\mathbf{K}$ & 3 & & 2 & $\mathbf{R p}_{\mathrm{p}}$ & 560.000 & 540.000 \\
\hline $\mathbf{L}$ & 2 & & 1 & $\mathbf{R p}_{\mathbf{p}}$ & 405.000 & 385.000 \\
\hline $\mathbf{M}$ & 4 & & 3 & $\mathbf{R}_{\mathbf{p}}$ & 812.500 & 1.302 .500 \\
\hline $\mathrm{N}$ & 5 & & 3 & $\mathbf{R p}_{\mathbf{p}}$ & 1.960 .000 & 1.960 .110 \\
\hline $\mathrm{O}$ & 3 & & 2 & $\mathbf{R p}_{\mathbf{p}}$ & 480.000 & 900.000 \\
\hline $\mathbf{P}$ & 1 & & 1 & $\mathbf{R}_{\mathbf{p}}$ & 165.000 & 165.000 \\
\hline $\mathbf{Q}$ & 7 & & 6 & $\mathbf{R p}_{\mathbf{p}}$ & 1.980 .000 & 1.980 .000 \\
\hline $\mathbf{R}$ & 3 & & 1 & $\mathrm{R}_{\mathrm{p}}$ & 510.000 & 730.000 \\
\hline $\mathrm{S}$ & 1 & & 1 & $\mathbf{R p}_{\mathbf{p}}$ & 160.000 & 160.000 \\
\hline$T$ & 1 & & 1 & $\mathbf{R p}_{\mathbf{p}}$ & 70.000 & 70.000 \\
\hline $\mathbf{U}$ & 1 & & 1 & $\mathbf{R p}_{\mathbf{p}}$ & 82.000 & 82.000 \\
\hline $\mathrm{V}$ & 2 & & 2 & $\mathrm{Rp}_{\mathrm{p}}$ & 197.000 & 197.000 \\
\hline $\mathbf{W}$ & 1 & & 1 & $\mathbf{R}_{\mathbf{p}}$ & 170.000 & 170.000 \\
\hline $\mathrm{x}$ & 7 & & 6 & $\mathbf{R}_{\mathbf{p}}$ & 490.000 & 1.150 .000 \\
\hline $\mathbf{Y}$ & 2 & & 1 & $\mathbf{R p}_{\mathbf{p}}$ & 25.000 & 25.000 \\
\hline \multicolumn{4}{|c|}{ TOTAL } & $\mathbf{R}_{\mathbf{p}}$ & 17.227 .500 & 20.127 .610 \\
\hline \multicolumn{7}{|c|}{ Which will be Crashed (Critical Path) } \\
\hline Activity & Total Accelera & & \multicolumn{2}{|c|}{ Fotal Acceleration Cos } & \multicolumn{2}{|c|}{ Acceleration Fee Per Day } \\
\hline A & \multirow{2}{*}{\multicolumn{2}{|c|}{$\frac{O}{4}$}} & $\mathbf{R}_{\mathbf{p}}$ & -1 & $\mathbf{R}_{\mathbf{p}}$ & - \\
\hline C & & & $R_{p}$ & - & \multirow{2}{*}{$\frac{R_{p}}{R_{p}}$} & - \\
\hline $\mathbf{E}$ & \multicolumn{2}{|l|}{1} & $\mathbf{R p}_{\mathbf{p}}$ & 30.000 & & 230.000 \\
\hline $\mathbf{F}$ & \multicolumn{2}{|l|}{2} & $\mathbf{R p}$ & 60.000 & $\mathbf{R p}$ & 180.000 \\
\hline G & \multirow{2}{*}{\multicolumn{2}{|c|}{$\frac{1}{2}$}} & $\mathbf{R}_{\mathbf{p}}$ & 20.000 & $\mathbf{R}_{\mathbf{p}}$ & 420.000 \\
\hline $\mathbf{H}$ & & & $\mathbf{R}_{\mathbf{p}}$ & 10.000 & $\mathbf{R}_{\mathbf{p}}$ & 105.000 \\
\hline $\mathbf{I}$ & \multicolumn{2}{|l|}{1} & $\mathbf{R p}_{\mathbf{p}}$ & 70.000 & $\mathbf{R}_{\mathbf{p}}$ & 70.000 \\
\hline $\mathbf{Y}$ & \multicolumn{2}{|l|}{$\begin{array}{c}1 \\
12\end{array}$} & $\mathbf{R}_{\mathbf{p}}$ & - & $R_{p}$ & - \\
\hline Total & \multicolumn{2}{|l|}{12} & $\mathbf{R}_{\mathbf{p}}$ & 90.000 & $\mathbf{R p}_{\mathbf{p}}$ & 1.005 .000 \\
\hline
\end{tabular}

From the cost of accelerating the critical path, we choose the least cost:

Crashing/First Acceleration
C activity
Activity Time after
Acceleration
$=6-4=2$ days
Project Time
Acceleration after
$=42-4=38$ days (not
according to the
acceleration target)
Additional Cost after
Acceleration

$=\operatorname{IDR} 0 * 1=\operatorname{IDR} 0$

- Crashing/Second Acceleration Y.activity

Activity Time after Acceleration

= 2-1 = 1day

Project Time after

Acceleration

$=38-1=37$ days $\quad($ not according to acceleration target)

Additional Cost after Acceleration

$=\operatorname{IDR} 0 * 1=\operatorname{IDR} 0$ 


\section{Tibuana}

Journal of applied Industrial Engineering-University of PGRI Adi Buana

DOI : https://doi.org/10.36456/tibuana.4.02.3770.69-82

- Crashing/Third Acceleration

I. activity

Activity Time after

Acceleration

$=7-1=6$ days

Project Time after

Acceleration

$=37-1$ = 36days (already according to acceleration target)

$$
\begin{aligned}
& \text { Additional Cost after } \\
& \text { Acceleration } \\
& =\text { IDR 70,000 * } 1=\text { IDR } \\
& 70,000
\end{aligned}
$$

For the length of time the project also changes as in the following table table Project Time After Crash $($ Initial Time $=42)$

Table 10. Crashing Activities

\begin{tabular}{|c|c|c|}
\hline Incident & Acceleration time used & Project Time Afrer Acceleration \\
\hline$C$ & 4 & 38 \\
\hline$Y$ & 1 & 37 \\
\hline$I$ & 1 & 36 \\
\hline
\end{tabular}

Because the project time is the same as the expected time, the carsh stops. So that the total additional cost to speed up time

\begin{tabular}{|c|c|c|c|}
\hline Incident & $\begin{array}{l}\text { Acceleration Time } \\
\text { Used }\end{array}$ & $\begin{array}{l}\text { Acceleration fee per } \\
\text { week }\end{array}$ & $\begin{array}{l}\text { Acceleration fee } \\
\text { amount }\end{array}$ \\
\hline c & 4 & $\mathrm{R} p O$ & $\mathrm{R}_{\mathrm{P}} \mathrm{O}$ \\
\hline $\mathbf{Y}$ & 1 & $\mathrm{RpO}$ & Rpo \\
\hline I & 1 & $\mathrm{Rp} 70.000$ & Rp 70.000 \\
\hline \multicolumn{3}{|c|}{ Total biaya tambahan setelah akselerasi } & $\mathrm{Rp} 70.000$ \\
\hline
\end{tabular}
is 36 days according to the table below.

Table 11. Crashing Costs Estimation

So, the total additional cost after acceleration is IDR 70,000 . So the total after crashing is IDR $17,297,500$.

L. Effect of Crashing on the Countdown

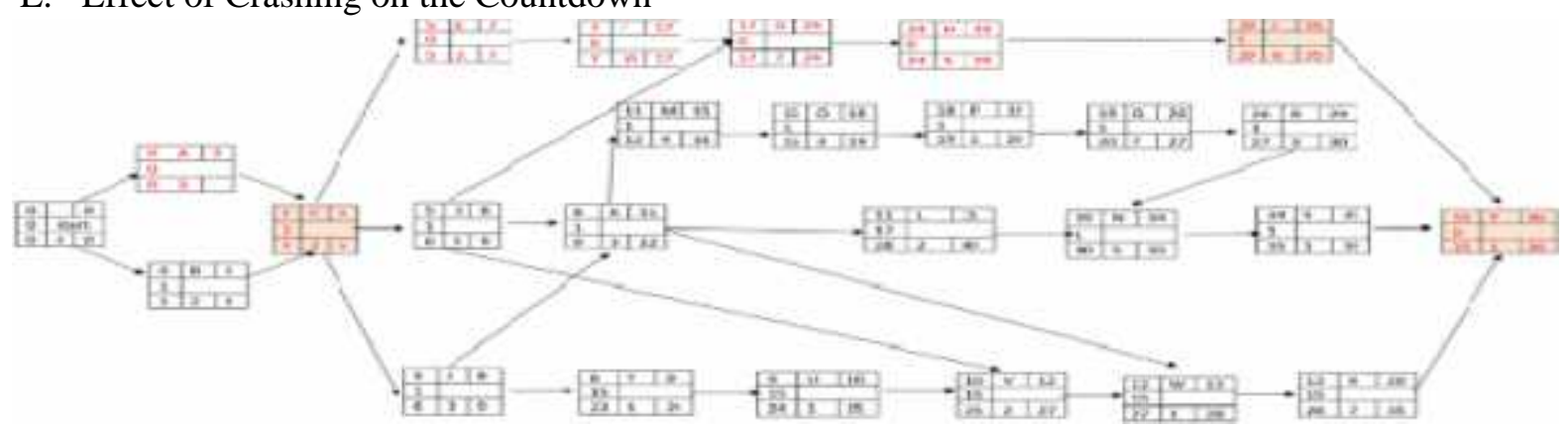

Figure 5. Network iteration in crashing project

After we get what activities have been crashed, we recalculate the forward and backward calculations with the duration of the crashing activities being changed according to the crash duration.
So that we get the appropriate total processing time, which is 36 days, and the critical path remains on activities A - C - E - F - G - H - I - Y with accelerated activities, namely activities $\mathrm{C}$, I and $\mathrm{Y}$. 


\section{Tibuana}

Journal of applied Industrial Engineering-University of PGRI Adi Buana

DOI : https://doi.org/10.36456/tibuana.4.02.3770.69-82

M. The Effect of Crashing on the Gantt Chart

Table 12. New Gantt Chart after Crashing

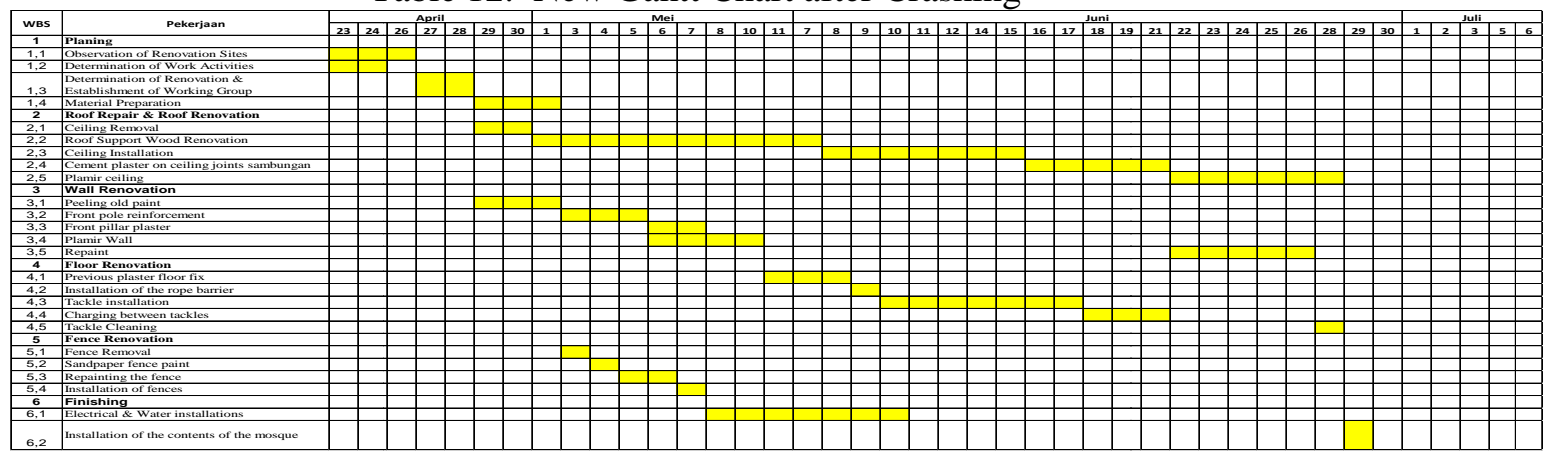

The following is a gantt chart after crashing. Where, after crashing, the project can be completed on June 29 (duration 36 days according to

N. Effect of Crashing on Resource Scheduling acceleration target).

Table 13. New Resource Scheduling

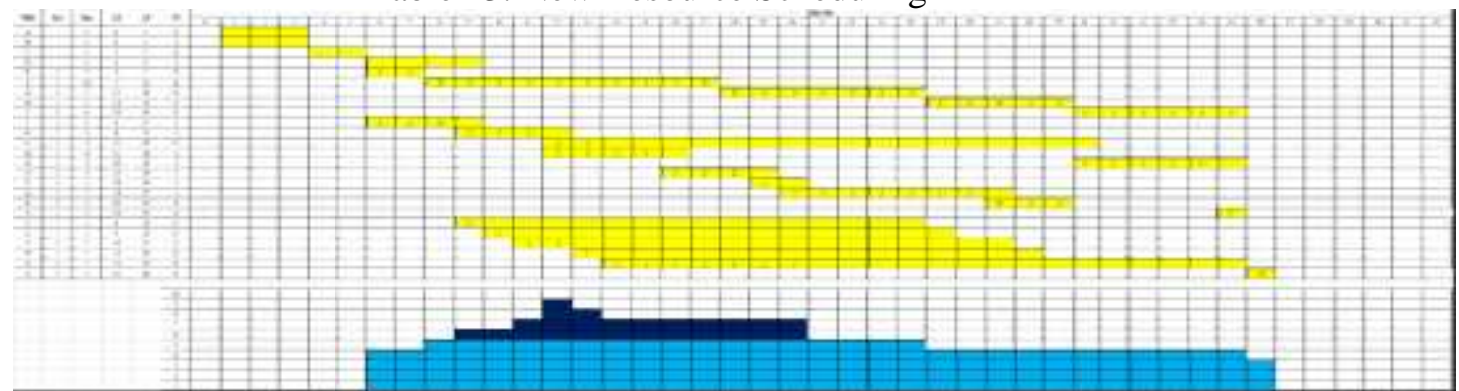

Table 14. New Resource Allocation

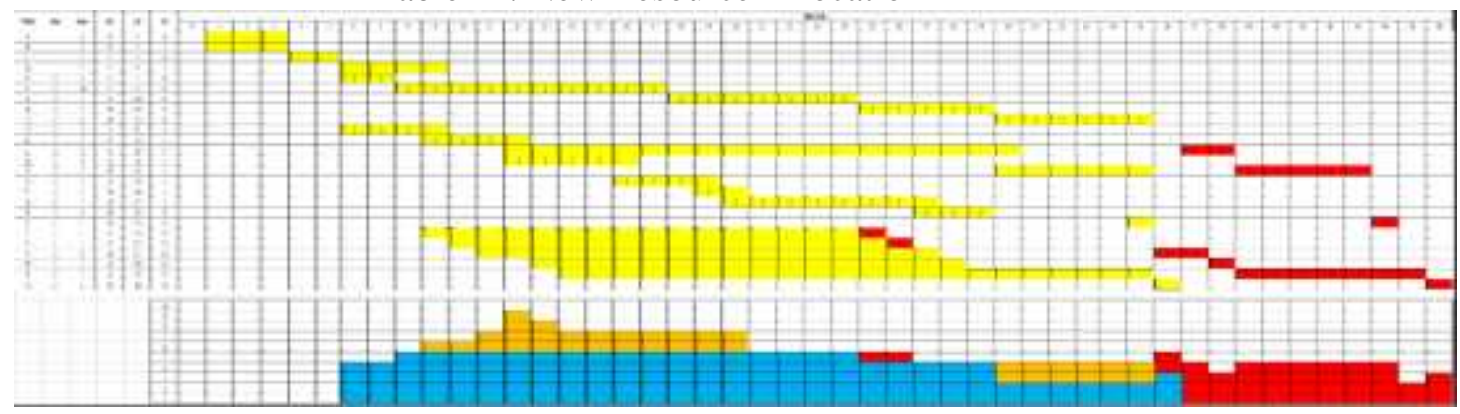

So, based on Resource after Crashing this Project is back 46 days until the completion of the project . While the request for project acceleration is 36 days, in the crashing process there is still a 10 day setback due to limited workers. So we tried another way as follows; 


\section{Tibuana}

Journal of applied Industrial Engineering-University of PGRI Adi Buana

DOI : https://doi.org/10.36456/tibuana.4.02.3770.69-82

O. Checking the Planer Team Sheet (Ms. Project)

To find out workers who are overloaded

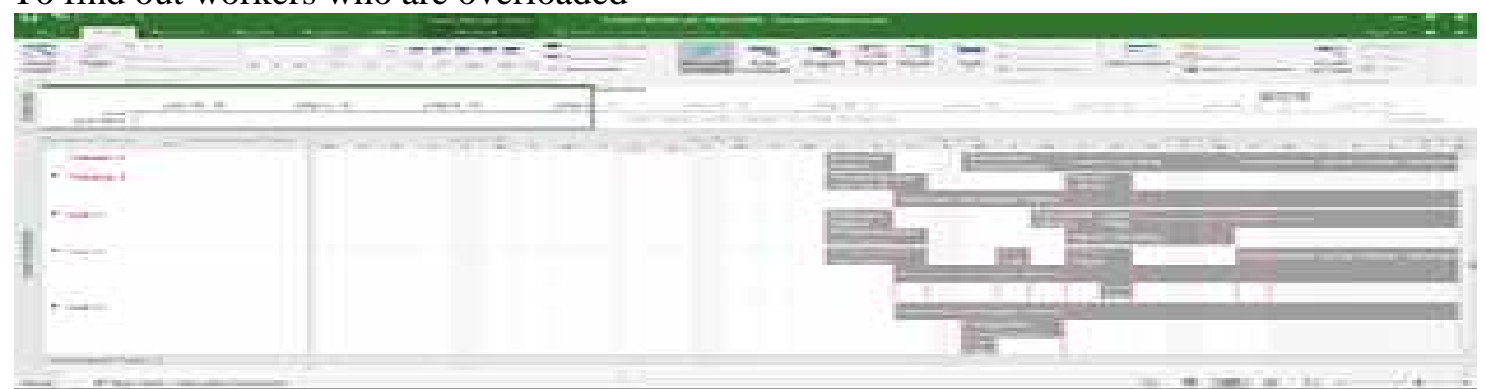

Figure 6. Resource Scheduling using Ms, Project

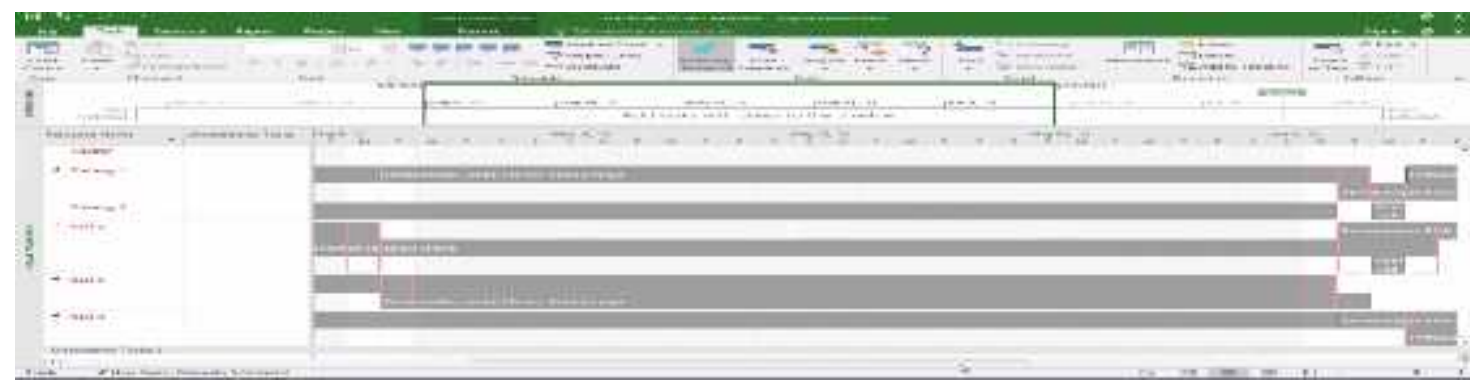

Figure 7. Resource Scheduling (cont..)

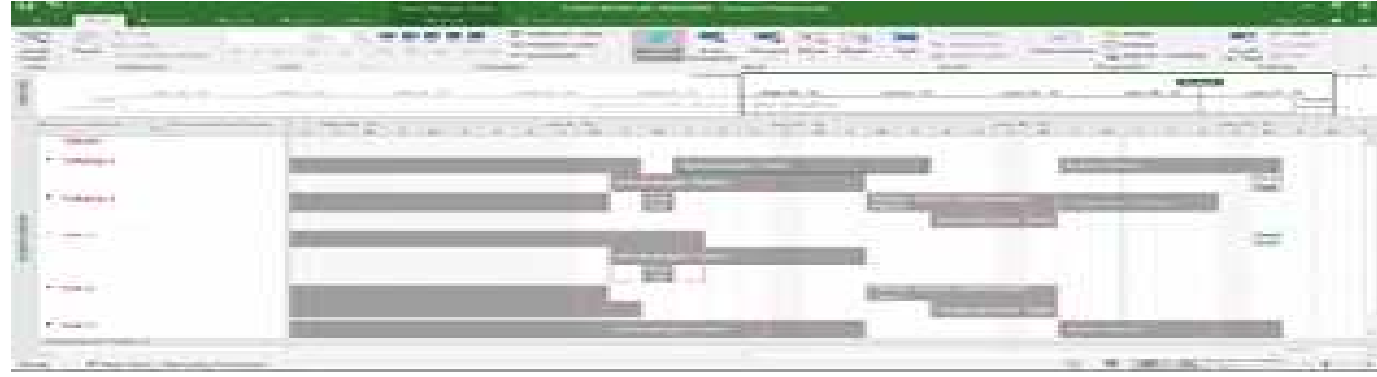

Figure 8. Resource Scheduling (cont...)

From the team planer above, it can be seen that overtime is at; P1 : 7 days

$\mathrm{P} 2: 6$ days

$\mathrm{P} 3: 8$ days

P4 : 9 days

P5: 13 days

Which is where the overtime fee is $50 \%$ of the wages of each worker
$\mathrm{P} 1: 7$ days $* \operatorname{Rp} 45,000=\operatorname{Rp} 315,000$

$\mathrm{P} 2: 6$ days $* \operatorname{Rp} 45,000=\operatorname{Rp} 270,000$

P3 : 8 days $* \operatorname{Rp} 35,000=\operatorname{Rp} 280,000$

P4 : 9 days $* \operatorname{Rp~} 35,000=\operatorname{Rp} 315,000$

$\mathrm{P} 5: 13$ days $* \mathrm{Rp} 35,000=\underline{\mathrm{Rp} 455.00}+$

Rp 1,635,000

So that the total number of overtime workers is Rp. 1,635,000. 


\section{Tibuana}

Journal of applied Industrial Engineering-University of PGRI Adi Buana

P. Check Ms. Project (Balancing)

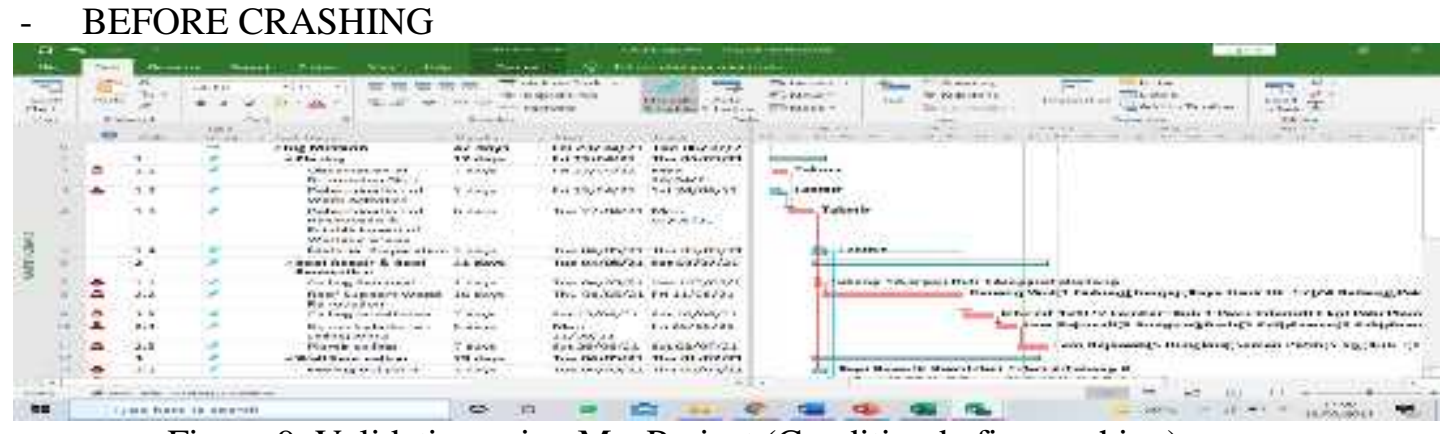

Figure 9. Validation using Ms. Project (Condition befire crashing)

Which is where the total duration is 42 days (the same as the duration before Crashing)

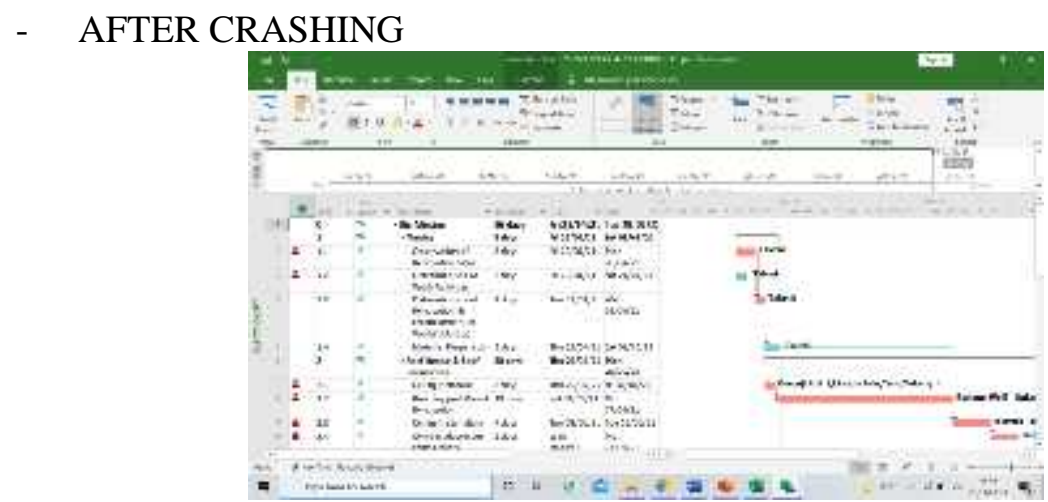

Figure 10. Validation using Ms. Project (Condition after crashing)

Which is where the total duration is 36 days (the same as the duration after the Crash).

\section{CONCLUSION}

From the analysis above, it can be concluded that the project acceleration time is up to 36 days using the CPM-Pert method. On the network it is stated that the project can be completed in 36 days. However, it turns out that in resource scheduling there is still a setback in completion for 10 days due to a lack of manpower. With the addition of costs for the overtime system for workers in order to complete the project for 36 days.

So, the project costs are added to the crashing process costs of Rp. 70,000 and there

\section{REFERENCES}

[1] Abdurrasyid, Luqman, Haris, A., \& Indrianto. (2019). Implementation of PERT and CPM Methods on Shipbuilding Project Management Information System. Journal is an overtime system for workers at a cost of Rp. $1,635,000$ so that the total cost is $\mathrm{Rp}$. $18,932,500$ to complete the renovation project of Nurul Hayat's mosque for 36 days.

After that, input the project information data that is being carried out on Ms. project and get a balance between Ms. Projects with manual work. That is, before crashing produces a duration of 42 days and after crashing produces 36 days.

of Computer Science and Informatics, Vol. 5 No. 1, pp:28-36.

[2] Abror, H. (2008). Project Management. ANDI. 
Tibuana

Journal of applied Industrial Engineering-University of PGRI Adi Buana

DOI : https://doi.org/10.36456/tibuana.4.02.3770.69-82

$p$-ISSN 2622-2027

$e$-ISSN 2622-2035

[3] Arianie, G. P., \& Puspitasari, N. B. (2017).

Project Management Planning in Improving

Efficiency and Effectiveness of Company

Resources (Case Study: Qiscus Pte Ltd).

$J @ t i$ Undip: Jurnal Teknik Industri, Vol. 12, No. 3, pp : 189-196.

[4] Dannyanti. (2011). Optimalisasi Pelaksanaan Proyek dengan Metode PERT dan CPM (Studi Kasus Twin Tower Building Pasca Sarjana Undip).

[5] Dimyati, D., \& Nurjaman, K. (2014). Project Management. Yogyakarta: Pustaka Setia.

[6] Gunasti, A., Rofiqi , A., \& Priyono, P. (2019). Application of the Barchart, CPM, PERT and Crashing Project Methods in Scheduling the G . Building Construction Project Muhammadiyah University of Jember. Jurnal Rekayasa Tenik Sipil Universitas Madura, Vol. 4 No.1, pp : 712.

[7] Herjanto, E. (2008). Manajemen Operasi,. 3rd ed. Jakarta: Grasindo.

[8] Utomo, G., Hendriyani, I., \& Aida, S. (2020). Drainage Project Implementation Evaluation With The CPM And PERT Method. Media Ilmiah Teknik Sipil, Vol.9, No.1, pp: 44-52.

[9] Simatupang, J., Dundu, A., \& Sibi, M. (2015). The Effect Of Acceleration Of Duration On Time On Construction Projects (Case Study: Eben Haezar Manado School Development). Jurnal Sipil Statik, Vol.3 No.5, pp: 281-280.

[10] Wohon, F., Mandagi, R., \& Pratasis, P. (2015). Analysis Of The Effect Of Duration Acceleration On Cost Projects Using The Microsoft Project 2013 (Case Study: Gmim Syaloom Church Development Karombasan). Jurnal Sipil Statik, Vol.3 No.2, pp: 141-50. 